\title{
An Evaluation of the Writing Activities in the New Edition of English for Palestine 12 from Teachers' Perspective
}

\section{* Dr. Atef Mohammad Rasheed Shaath}

\section{Introduction}

In spite of the huge cluster of technology, science and knowledge; yet writing stands the central element for all the scientific achievements. Writing represents the permanent record of mankind history, culture, information and civilization, and it makes our thoughts and experiences vivid and long lasting. It plays a crucial role in social, cultural, occupational, business and academic contexts. Therefore, in the education process and acquiring knowledge, writing skill is considered a basic skill that every student should acquire from the start of his/her primary education. It is regarded as a means of strengthening and enhancing the other language main skills and subsidiary skills. In addition, it encourages creative thinking and developing one's thoughts.

Writing is an important activity and skill that is highly valued in the culture of all societies. It is an essential skill that aims at giving learners the opportunity to develop the proficiency they need. It is considered as one of the major means by which students demonstrate their knowledge and experience. It provides a powerful mechanism for communication, self-expression and self-reflection (Graham, 2006b).

* Ph. D. Degree in Education (Curriculum and Instruction of EFL) 
It helps students in discovering knowledge, stimulating thinking, probing knowledge and experience, and generating new ideas (Shaath, 2015). It makes students active learners rather than passive receivers of information. Nevertheless, it is considered the most difficult skill and most important invention in the language learning process.

Writing is a cornerstone in the language teaching setting. It plays an important role in promoting language acquisition as students deal with vocabulary and structure to communicate their ideas effectively. It is considered as a process which may be affected by the content of writing, the type of writing and the medium it is written in (Harmer, 2007). Furthermore, Hedge (2000) views writing as a result of strategies to manage the composing process that involves a number of activities such as: setting goals, generating information, selecting appropriate language, making a draft, reading and reviewing it, then revising and editing. Writing is a set of skills needed for composing a meaningful text, communicating ideas and conveying messages and information.

The choice of language teaching materials can determine the quality of learning/teaching procedure, and it can play a crucial role in students' success or failure (Mukundan, Nimehchisalem, \& Hajimohammadi, 2011). Awad (2013) demonstrates that there is an urgent need for a lot of research to pinpoint problems behind the teaching and learning of English at schools, and finding solutions for these problems. Therefore, particular attention must be paid to evaluate such materials based on valid and reliable instruments, since developing students' language skills process is frequently the main purpose of EFL/ESL programs. Evaluation of any teaching materials is based mainly upon the learners' needs, aspiration and interest. 
Therefore, syllabi every now and then need accurate analysis and comprehensive evaluation in order to be developed. The evaluation process is considered as part and parcel of the component of curriculum. It goes side by side with planning and implementing processes (Shaath, 2010). Evaluation provides with feedback to keep the educational system in adjustment. Moreover, evaluation of teaching material determines the points of strength and weakness, and determines the suitability and effectiveness of the target teaching materials. According to Aqel (2009), the main goal of evaluation studies is not merely to evaluate, but rather to obtain useful information for improving the curriculum and the textbooks, and that can help in testing and measuring the student's achievements.

It is an important national achievement to produce a Palestinian English Language Curriculum; English for Palestine series from 1 to 12, for teaching English as a Foreign Language in the Palestinian schools aiming to meet the needs of the Palestinian students, to develop the curriculum to meet the latest developments in English Teaching, and to introduce English from first grade rather than from the fifth like. Briefly, the Ministry of Education and Higher Education (2015) describes the new edition of English for Palestine as an up-to-date communicative English course which has been specially written for schools in Palestine.

The twelve levels systematically develop competence in the four language skills (listening, speaking, reading and writing) and encourage students to become confident users of English. Grades 11 and 12 further develop skills learnt in previous grades, broaden vocabulary, and thoroughly prepare students for their grade 12 Tawjihi examination. In the current study, attention is directed to writing activities included in the new edition of 
English for Palestine 12. Writing skill has been regarded as an important language skill in any language program intended to help learners to achieve success in such a productive skill. Hence, the researcher seeks to individualize the writing skill in his evaluative study out of English language textbook; English for Palestine 12.

\section{Literature Review}

English language teaching/learning has many important components but the textbook is the essential one for both teachers and students. Textbooks play a prominent role in the teaching/learning process, and they are the primary agents of conveying knowledge to learners. Besides, one of the basic functions of textbooks is to make the existence knowledge available and apparent to the learner in a selected, easy and organized way (Tok, 2010). Textbooks are a major part of the teaching/learning situation. Students are provided with the teaching material while teachers have it as a way of following guidelines, often determined by the local or central authorities.

Textbooks provide guidance for teachers and students. They present an attempt to distill and interpret the knowledge and scholarship of a given discipline. Additionally, textbooks give students information so that they may begin to understand individual concepts and general ideas (Henriques, 2009). In his part, Richards (2001) claims that without textbooks, a program may have no impact; therefore, they provide structure and a syllabus. Besides, the use of a textbook in a program can guarantee that students in different classes will receive a similar content and therefore, can be evaluated in the same way. Teachers feel that it is very difficult for them to teach systematically without a textbook. 
Furthermore, Sheldon (1988) points out that textbook do not only represent the visible heart of any ELT program, but also offer substantial advantages for both students and teachers. Whereas, Cunningsworth (1995) identifies a number of roles that textbooks can serve in the curriculum. He argues that textbooks are an effective resource for self-directed learning, an effective medium for presentation of new material, a source of ideas and activities, a reference source for students, a syllabus where they reflect pre-determined learning objectives, and support for less experienced teachers who are yet to gain confidence. According to Tomlinson (2001) argues that the textbook is the most convenient form of presenting materials, it helps to achieve consistency and continuation and it gives learners a sense of system, cohesion and progress.

Certain criteria should be taken into consideration when an EFL textbook is selected, for example; the characteristics of the audience, the culture of the community and the goal of the programs. Woodward (2000) states six principles of language course design: 1. conceptualizing the content, 2. assessing needs, 3 . formulating goals and objectives, 4. developing materials, 5. designing an assessment plan, and 6 . organizing the course. Accordingly, Senior (2006) clarifies that textbooks should have clear organizational structure, contain careful balanced and graded grammar, vocabulary, skills and task. Topics and themes are selected with attention to what is likely to be of interest to the presumed users. The accompanying teacher's book, written on the assumption that teachers will go through the book in a sequential manner, gives clear instructions as to how it should be used.

English language teaching (ELT) material developers and evaluators need to take a wide range of factors into consideration before they make decisions 
on the materials they develop or select for particular contexts (Mukundan, Nimehchisalem, \& Hajimohammadi, 2011). Newby (2000) clarifies that foreign language curricula have three main functions. First of all, they clarify objectives, content and methods in an educational program. Secondly, they regularize and thus ensure a certain uniformity of content and expected outcomes. Thirdly, they can guide the process of teaching and learning. Consequently, prior to selecting a textbook, educators should thoroughly examine the program curriculum. If the goals of the program are clear and well defined, the parallel with certain textbooks may become obvious (Geringer, 2002).

Walker (2003) points out the curriculum materials coordinate teaching and learning in vital ways. They help the teachers keep in mind the big picture of what should be taught and learned over months and years and keep in track of where they are in relation to planned programs. While, Cunningsworth (1984) offers the following set of guidelines which can form the basis of formulating a personalized criteria checklist having local relevance: the selected materials should be related to the teaching objectives, the material should utilize activities which are interesting, involving, and intellectually stimulating for the learners, the students should be able to relate personally to the subject matter used in the materials, and the materials should present and practice English in a systematic and comprehensive way.

Any adoption of a new policy, or a new methodology, is the result of social constraint. Educating incorporates the faithful transference of social values, as well as technical skills, according to the current social trends or social standards. In this way schools represent transforming forces aimed at molding 
students according to the social requirements (Henriques, 2009). Sheldon (1988) elucidates the need to evaluate textbooks for two reasons. First, the evaluation will help educators' program developers in making decisions on selecting the appropriate textbook. Furthermore, evaluation of the advantages and disadvantages of a textbook will familiarize teachers with its probable weaknesses and strengths. This will assist instructors to make appropriate adaptations to the material in their future instruction.

The textbook evaluation can help the reflective teacher to make necessary changes to a textbook by examining its weaknesses or strengths (Mukundan, 2010). On his part, Tomlinson (2003) asserts that evaluating language materials is very useful for language teachers. One essential consideration in evaluating language materials is that teachers can obtain views on its value. Teachers' involvement in the evaluation process can help them develop professionally. According to (Mukundan, Nimehchisalem, \& Hajimohammadi, 2011), both predictive and retrospective evaluations aim at making the teaching/learning environment more effective. They both help instructors to make appropriate judgment concerning the effectiveness of their teaching including the textbook they used.

In their parts, Cunningsworth (1995), \& Ellis (1997) proposes three types of textbook evaluation, namely: predictive or pre-use evaluation, in-use evaluation, and retrospective or post-use evaluation. Firstly: the predictive evaluation is designed to make a decision regarding what materials to use. Teachers who are required to carry out a predictive evaluation determine which materials are best suited to their purposes. Secondly: the in-use evaluation aids 
teachers to explore the weaknesses and strengths of the textbook while it is being used. Thirdly: the retrospective or post-use evaluation helps instructors reflect on the quality of the textbook after it has been used in a particular learning/teaching situation. Moreover, Mukundan \& Nimehchisalem (2012) clarify that textbooks may be evaluated implicitly (following the evaluator's impressionistic judgment) or explicitly (using an instrument).

Learners, teachers and instructional materials are the main factors that should be taken into consideration before any textbook evaluation. The evaluator should gain a adequate awareness of the learners and teachers' needs and interests, and the instructional materials context. The relevant literature abounds of various evaluative studies of English Language textbooks, locally and globally. Locally, some previous studies dealt with the Palestinian English language textbooks for different levels, using different criteria and examining different domains and aspects. It is reasonable to clarify that the researcher grouped the Palestinian previous evaluative studies according the scholastic stages, arranging them chronologically.

Hammad (2014), Awad (2013), Abbas (2011), ElShawa (2011), Abu Ashiba (2010), \& Aqel (2009) evaluated English Language textbooks for grades 11 \& 12. Hammad (2014) revealed that the participants had positive (high) attitudes towards the English materials in that the topics in such materials were perceived by the teachers to be relevant to pupils' cultural background and needs. Also, Awad (2013) indicated that textbooks could be suitable for the Palestinian students of grade 12, their culture and religion. Abbas (2011) showed that the books were very rich in these 
various cultural aspects and that these various dimensions were interwoven and interrelated.

Similarly, El-Shawa (2011) showed several advantages, including: most activities were culturally oriented; there was wealthy presentation of various countries and cultures from different parts of the world, which indicated intercultural learning. Abu Ashiba (2010) showed variation in the frequencies. Cultural values domain scored the highest score of frequencies, followed respectively by theoretical values, economic values, social values, aesthetic values, patriotic values, religious and political domain. Whereas, Aqel (2009) pointed out that the Palestinian 11th grade textbook should be enriched with a variety of literary forms such as poems and essays in addition to reducing the number of units in this textbook for the sake of covering the material effectively.

Likewise, Al-Najjar (2012), Shaath (2010), Mahmoud (2008), Al Mazloum (2007), \& Badawi, (2007) evaluated the English language textbook for grade 10. Al-Najjar (2012) revealed that pronunciation teaching content of English for Palestine 10 falls short in adopting the suggested characteristics of pronunciation teaching content that match current perspectives in pronunciation pedagogy. Differently, Shaath (2010) indicated that the total degree of evaluation is moderate with percentage $(68.13 \%)$. On his study, Mahmoud, (2008) stressed that these textbooks were suitable, but lacked few items that characterize a good textbook. Therefore, he strongly recommended modifying the time used to cover the included materials. He also overstressed the active participation of parents, supervisors and teachers in the choice of the included materials.

Accordingly, Al Mazloum (2007) revealed that communication was strongly represented in the 
mentioned textbook whereas the connection standards were poorly represented due to the lack of employment of the integrated curriculum. At the same year, Badawi, (2007) showed a variance in presenting the standards of the foreign language learning. Communications standards were highly dominant in contrast with communities, connections and cultures standards. He pointed out that there should be more balance in the distribution of the standards among the units of the textbook.

In addition, Abu-Alhumous (2010), Ali (2010), Faqawi (2010), Fattash (2010), Hamdona (2007), \& Masri (2003) evaluated the English language textbooks for different grades for basic stages. Abu-Alhumous (2010) showed that most of the students in the first grade got very little practice on reading enough words or connected texts. This lack of repetition and recycling contradicts with the word, sentence and text approach that English for Palestine adopts. Similarly Ali (2010) revealed several areas of weakness, such as: lack of authentic reading texts, extensive reading was not included, and several reading skills were neglected such as: employing exercises that require students to infer the author's attitude, distinguish between fact and opinion, recognize pronoun references, find meanings of new vocabulary in contexts, relate the text to their personal experience, and work out answers in pairs and groups.

On his part, Faqawi (2010) found out that the reading skill occupied the first position of the English language skills, the listening and speaking skills occupied the second position, and the writing skill occupied the third position. At the same year, Fattash (2010) revealed that reading materials in the textbooks were perceived by teachers to be interesting and relevant to students' cultural background. In his study, 
Hamdona (2007) revealed that communication skills were the prominent domain followed by personal/social, leadership, decision making, problem solving and critical thinking respectively. He stressed the importance of critical thinking and leadership life skills activities to be included in the textbooks. Nevertheless, Masri (2003) showed that the degrees of evaluation of the book shape and content domains, the structure and the grammar, and the methods and aids were high with total score.

In a similar vein, some globally previous study dealt with the English language textbooks for different levels evaluating different domains and aspects. Anjaneyulu (2014) emphasized that planning is important for preparing a relevant curriculum. Curriculum should be planned according to what students need to learn. Whereas, John, Abdul Aziz, Ahmed, Sharf, \& Ishaque (2014) showed that the teaching did not get chance to go through the curriculum, and the textbooks contents did not match with the specifications given in the National Language Curriculum-2006 which was the latest curriculum developed in Pakistan.

In addition, Mukundan \& Nimehchisalem (2012) developed an instrument to evaluate English language teaching textbooks. The evaluators turned out to be highly satisfied with the checklist and highly agreed on its usefulness. Mukundan, Hajimohammadi, \& Nimehchisalem (2011) commenced their study in the form of an unstructured interview in which the participants brainstormed on the evaluative criteria that should be considered in evaluating ELT textbooks. Further, Tok (2010) pointed out that "Spot On" textbook actually did not stand up reasonably well to a systematic in depth analysis and that the negative attributes far outweighed the positive characteristics. Nevertheless, Henriques (2009) revealed that the two 
Angolan EFL textbooks were considered to be inappropriate for achieving the goals set forth by the Angolan Institute for the Development of Education.

Based on the previous evaluative studies related to English Language textbooks, some essential points were highlighted; where, researchers asserted the importance of evaluating textbooks every now and then, as evaluation process is considered as part and parcel of the curriculum. Educators and researchers in different countries were concerned with evaluating EFL textbooks. Moreover, teachers were essential in evaluating textbooks. Furthermore, evaluative checklists were administered in most of the previous studies as the main instrument, while different aspects and domains of textbooks were evaluated. Otherwise, it has been appeared a variation in the Palestinian evaluative studies of English language textbooks; where some research have demonstrated satisfaction to some extent about the evaluated textbooks, others pointed out some dissatisfactions and shortcomings. in some aspects.

\section{Statement of the Problem}

The current study tries to evaluate the writing activities included in the newly introduced English Language Textbook English for Palestine 12 for grade 12 at the Palestinian governmental schools. It is of great benefits to participate in achieving an evaluation for a newly introduced textbook, to overcome challenges of modern time and modify any shortage in a productive skill like writing. It is essential to examine the appropriateness and suitability of the writing activities included in the New Edition of English for Palestine 12. 


\section{Questions of the Study}

The problem of the current study can be identified in the following main question:

\section{"What are the appropriateness and suitability of the writing activities included in the New Edition of English for Palestine 12 for the students of grade 12?"}

From the main question; the following sub-questions emerge:

1. What are the criteria for evaluating the writing activities included in the New Edition of English for Palestine 12?

2. What are the teachers' evaluative estimations for the writing activities included in the New Edition of English for Palestine 12?

3. What are the degrees of evaluation for the writing activities included in the New Edition of English for Palestine 12?

\section{Aims of the Study}

The current study aims at:

1. identifying criteria for evaluating the writing activities included in the New Edition of English for Palestine 12.

2. investigating teachers' evaluative estimations for the writing activities included in the New Edition of English for Palestine 12.

3. exploring teachers' attitudes towards the writing activities included in the New Edition of English for Palestine 12.

4. examining the appropriateness and suitability of the writing activities included in the New Edition of English for Palestine 12. 


\section{Delimitations of the Study}

The current study is delimited to:

* The writing activities included in the New Edition of "English for Palestine 12" in the scholastic year 2015/2016.

* English language teachers' perspective of 12th grade at the governmental schools in Khan Younis Directorates.

- English language teachers' attitudes towards the writing activities included in the New Edition of "English for Palestine 12".

Administering the study during the second semester of the scholastic year 2015/2016.

\section{Significance of the Study}

To the best of the researcher's knowledge, the current study is important as it evaluates the writing activities included in the New Edition of English for Palestine 12, which has been taught for the first time in the scholastic year 2015/2016. Therefore, it is hopeful that the current study will:

participate in the evaluation process of the new edition of English for Palestine 12.

* give English language teachers opportunity to participate in the evaluation process and get oriented to the newly introduced English language textbook English for Palestine 12.

provide the syllabus designer with a feedback about writing skill.

shed light on the importance of writing as a productive skill.

* check up teachers' satisfaction with the new edition of English for Palestine 12.

* be a pioneer attempt to evaluate the writing activities out of the new edition of English for Palestine 12. 


\section{Definition of Terms}

English for Palestine 12: It is designated and dedicated for the final year in the secondary stage (Grade 12) at Southern and the Northern governorates schools in Palestine. The English for Palestine Grade 12 package consists of the following components:

1. New edition, English for Palestine 12, Pupil's Book: This is the core English language book, to be used for all courses. It contains (143) pages. It is divided into 12 units; each unit includes writing activities.

2. New edition, English for Palestine 12, Pupil's Book - Reading Plus: This is the advanced literary book, which is an additional component for more intensive English courses. It contains (111) pages. It is divided into 6 units; each includes writing activities.

3. New edition, English for Palestine 12 - Teacher's Book: It includes full instructions for carrying out the activities in class, answer keys and audio scripts for the listening activities.

4. In addition, an audio CD is provided.

Each unit is based on a theme, allowing the new language to be taught in context, e.g. making a new start, under pressure, coincidences. The theme in each unit of Pupil's Book 12 is mirrored in a related theme in Pupil's Book 12 Reading Plus. The themes have been taken from the Palestinian curriculum to meet the needs and interests of pupils of this age.

Evaluation: It is an organized process for collecting data for determining the degree of achieving the objectives and making decisions concerning them. According to Brown (1988) cited in Richards (2001), evaluation is the systematic collection and analysis of all relevant information necessary to promote the 
improvement of a curriculum and assesses its effectiveness and efficiency as well as the participants attitudes within the context of the particular institution involved.

Writing Activities: they are the teaching/learning procedures intended to stimulate writing skill through actual experience and participation. Writing activities are mostly found towards the end of each unit in the target textbook. Different techniques are used and various writing genres are taught/ learnt.

\section{Method}

\section{Design of the Study}

The descriptive analytical method is based upon analyses and justifications of the data available for the study. It is used to elicit the perspective of a representative sample of English language teachers of 12th grade (General Secondary Class) at the governmental schools in Khan Younis Governorate.

\section{Population of the Study}

The population of the current study consisted of about (100) English language teachers who teach English for 12th grade at the schools of Khan Younis Governorate according to the statistics of both West Khan Younis Directorate of Education \& East Khan Younis Directorate of Education during the second semester (2015/2016).

\section{Subjects of the Study}

The sample of the current study consisted of (42) English language teachers of the general secondary class. The sample represented about $42 \%$ of the population of the study.

\section{Instrumentation}

A Checklist designed by the researcher is administered in the current study to collect data and information needed for evaluating and determining the appropriateness and suitability of the writing activities 
included in the English language syllabus for students of grade 12, which has been taught for the first time in the scholastic year 2015/2016. The Checklist is developed to cover different domains. The items of the Checklist are adopted from reviewing literature related to writing skills, and previously designed checklists concerned with evaluating EFL textbooks (Miekley, 2005; Henriques, 2009; Shaath, 2010; Tok, 2010; Mukundan, Nimehchisalem \& Hajimohammadi, 2011; Mukundan \& Nimehchisalem, 2012; Awad, 2013; Hammad, 2014). In addition, the objectives and procedures of teaching writing activities included in English for Palestine 12 were reviewed. As well as a Content Analysis Card is employed.

\section{Validity of the Instrument}

To ensure the validity of scale (Checklist); it was submitted to a panel of jury consisted of seven members specialized in curriculum and instruction of English as a foreign language to determine the appropriateness and suitability of the Checklist items to be fit for evaluating the activities of writing skill included in the English language syllabus for students of grade 12 .

\section{Reliability of the Instrument}

To determine the reliability of the instrument; Alpha Cronbach and Split-half techniques were administered for a pilot study of ten participants. Alpha Cronbach coefficient is (.781). This emphasizes the appropriateness and suitability of the Checklist items for conducting such an evaluative study.

Table (1) Reliability Statistics

\begin{tabular}{|c|c|c|}
\hline Cronbach's Alpha & $\begin{array}{c}\text { Cronbach's Alpha Based on } \\
\text { Standardized Items }\end{array}$ & N. of Items \\
\hline $\mathbf{7 8 1}$ & .797 & 5 \\
\hline
\end{tabular}




\section{Procedures of the Study}

The researcher developed the instrument of the study (a Checklist) and established its validity and reliability. The sample of the study consisted of (42) English language teachers of general Secondary class. The copies of the Checklist were distributed and collected by the researcher himself. In order to analyze the data available; the (SPSS) statistical package was administered to accomplish the questions of the study. The statistical procedures used in the study were: sum of responses (frequencies), means, standard deviations and weight (percentages). Additionally, the Alpha Cronbach test was computed. Finally, the results of the study were discussed and the recommendations were set up.

\section{Results and Discussion}

For data analysis, a five-point scale was administered, and the percentages were as follows (Akef, 2015):

$1(80 \%)$ and more is a Very High degree of evaluation.

2. (70-79.9\%) is a High degree of evaluation.

3. $(60-69.9 \%)$ is a Moderate degree of evaluation.

4. $(50-59.9 \%)$ is a Low degree of evaluation.

5. (Less than $50 \%$ ) is a Very Low degree of evaluation.

To answer the first sub-question of the study which is; "What are the criteria for evaluating the writing activities included in the New Edition of English for Palestine 12?" A Checklist of 50 items divided into five domains was designed. These five domains are: A. Pedagogical Domain, B. EFL Methodology Domain, C. Writing Themes Domain, D. Writing Skill and SubSkills Domain, and E. Teachers' Attitudes Domain. Each domain contains ten essential items. The items of the checklist were adopted from reviewing literature related to writing skills and evaluating EFL textbooks, 
and reviewing previously checklists designed for evaluating EFL textbooks. In addition, reviewing objectives and procedures of teaching the writing activities included in the New Edition of English for Palestine 12.

To answer the second sub-question of the study which is: "What are the teachers' evaluative estimations for the writing activities included in the New Edition of English for Palestine 12?" Sum, Means, standard deviations and \% weight were computed, and Level/Degree is also provided.

A. Pedagogical skill Domain Table (2)

Sum of Responses, Means, Std. Deviation, \% Weight and Level/Degree

\begin{tabular}{|c|c|c|c|c|c|}
\hline No. & Items & Sum & Mean & $\begin{array}{c}\% \\
\text { Weight }\end{array}$ & $\begin{array}{c}\text { Level/ } \\
\text { Degree }\end{array}$ \\
\hline 1 & $\begin{array}{l}\text { The writing activities involve } \\
\text { students in the brainstorming } \\
\text { process. }\end{array}$ & 174.0 & 4.14 & 82.86 & $\begin{array}{l}\text { Very } \\
\text { High }\end{array}$ \\
\hline 2 & $\begin{array}{l}\text { The writing activities stimulate the } \\
\text { higher level thinking skills. }\end{array}$ & $\begin{array}{ll}170.0 \\
\end{array}$ & 4.05 & 80.95 & $\begin{array}{l}\text { Very } \\
\text { High }\end{array}$ \\
\hline 3 & $\begin{array}{l}\text { The writing activities promote } \\
\text { creativity. }\end{array}$ & 168.0 & 4.00 & 80.00 & $\begin{array}{l}\text { Very } \\
\text { High }\end{array}$ \\
\hline 4 & $\begin{array}{l}\text { The writing activities motivate } \\
\text { students to participate in class work. }\end{array}$ & 152.0 & 3.62 & 72.38 & High \\
\hline 5 & $\begin{array}{l}\text { The writing activities reinforce } \\
\text { individual work and autonomy. }\end{array}$ & 144.0 & 3.43 & 68.57 & Moderate \\
\hline 6 & $\begin{array}{l}\text { The writing activities incorporate } \\
\text { pair and group work, and } \\
\text { collaborative writing. }\end{array}$ & 148.0 & 3.52 & 70.48 & High \\
\hline 7 & $\begin{array}{l}\text { The writing activities enhance Self- } \\
\text { Regulation Strategies (goal-setting, } \\
\text { self-instruction, self-monitoring, } \\
\text { self-evaluating, self-reinforcement, } \\
\text { etc.). }\end{array}$ & 144.0 & 3.43 & 68.57 & Moderate \\
\hline 8 & $\begin{array}{l}\text { The writing activities develop self- } \\
\text { reflective writing. }\end{array}$ & 158.0 & 3.76 & 75.24 & High \\
\hline 9 & $\begin{array}{l}\text { The writing activities demonstrate } \\
\text { students' ability to generate ideas, } \\
\text { and enhance free writing. }\end{array}$ & 160.0 & 3.81 & 76.19 & High \\
\hline 10 & $\begin{array}{l}\text { The writing activities participate in } \\
\text { increasing writing knowledge and } \\
\text { awareness. }\end{array}$ & 158.0 & 3.76 & 75.24 & High \\
\hline \multirow{2}{*}{\multicolumn{2}{|c|}{$\begin{array}{c}\text { Total score of the Pedagogical skill } \\
\text { Domain }\end{array}$}} & 1576.0 & 37.52 & 75.05 & \multirow[t]{2}{*}{ High } \\
\hline & & \multicolumn{2}{|c|}{ Std. Deviation } & 10.699 & \\
\hline
\end{tabular}

Table (2) indicates that Item (1) is the highest with percentage (82.86\%), and Item (7) is the lowest with 
percentage $(68.57 \%)$. It illustrates that the degree of evaluation was from "Very High" downward to "Moderate". The average degree of the total score is "High".

B. EFL Methodology Domain Table (3)

Sum of Responses, Means, Std. Deviation, \% Weight and Level/Degree

\begin{tabular}{|c|c|c|c|c|c|}
\hline No. & Items & Sum & Mean & $\begin{array}{c}\% \\
\text { Weight }\end{array}$ & $\begin{array}{l}\text { Level/ } \\
\text { Degree }\end{array}$ \\
\hline 1 & The writing activities are purposeful. & 160.0 & 3.48 & 69.52 & High \\
\hline 2 & $\begin{array}{l}\text { The periods of the writing activities } \\
\text { have achievable goals. }\end{array}$ & 146.0 & 4.05 & 80.95 & Moderate \\
\hline 3 & $\begin{array}{l}\text { Instructions of the writing activities } \\
\text { are clear and understandable. }\end{array}$ & 160.0 & 3.81 & 76.19 & High \\
\hline 4 & $\begin{array}{l}\text { Students are involved in the writing } \\
\text { process steps (planning/pre-writing, } \\
\text { drafting, revising, and editing). }\end{array}$ & 148.0 & 3.52 & 70.48 & High \\
\hline 5 & $\begin{array}{l}\text { The writing activities assist students } \\
\text { who are under/over-achievers and } \\
\text { take into consideration the } \\
\text { individual differences. }\end{array}$ & 150.0 & 3.57 & 71.43 & High \\
\hline 6 & $\begin{array}{l}\text { The writing activities are compatible } \\
\text { with the diversity of students' } \\
\text { background knowledge and } \\
\text { capabilities. }\end{array}$ & 156.0 & 3.71 & 74.29 & High \\
\hline 7 & $\begin{array}{l}\text { The writing activities are graded and } \\
\text { progressive, and tasks move from } \\
\text { simple to complex. }\end{array}$ & 140.0 & 3.33 & 66.67 & Moderate \\
\hline 8 & $\begin{array}{l}\text { Assessment and corrective feedback } \\
\text { are provided. }\end{array}$ & 156.0 & 3.71 & 74.29 & High \\
\hline 9 & $\begin{array}{llll}\text { Important writing } & \text { models } & \text { are } \\
\text { recycled. } & & & \\
\end{array}$ & 152.0 & 3.62 & 72.38 & High \\
\hline 10 & $\begin{array}{l}\text { The writing activities focus on } \\
\text { writing as a process. }\end{array}$ & 150.0 & 3.57 & 71.43 & High \\
\hline \multirow{2}{*}{\multicolumn{2}{|c|}{$\begin{array}{l}\text { Total score of the EFL Methodology } \\
\text { Domain }\end{array}$}} & 1518.0 & 36.14 & 72.29 & \multirow[t]{2}{*}{ High } \\
\hline & & \multicolumn{2}{|c|}{ Std. Deviation } & 6.356 & \\
\hline
\end{tabular}

Table (3) indicates that Items $(1 \& 3)$ are the highest with percentage (76.19\%) and Item (7) is the lowest with percentage $(66.67 \%)$. It illustrates that the degree of evaluation was from "High" downward to "Moderate". The average degree of the total score is "High". 


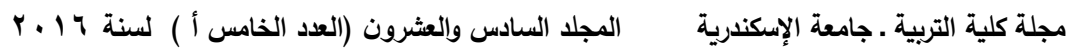

C. Writing Skill \& Sub-Skills Domain Table (4)

Sum of Responses, Means, Std. Deviation, \% Weight and Level/Degree

\begin{tabular}{|c|c|c|c|c|c|}
\hline No. & Items & Sum & Mean & $\begin{array}{c}\% \\
\text { Weight }\end{array}$ & $\begin{array}{l}\text { Level/ } \\
\text { Degree }\end{array}$ \\
\hline 1 & $\begin{array}{l}\text { The writing activities are consistent } \\
\text { and integrated with other activities of } \\
\text { language skills. }\end{array}$ & 172.0 & 4.10 & 81.90 & $\begin{array}{l}\text { Very } \\
\text { High }\end{array}$ \\
\hline 2 & $\begin{array}{l}\text { Attention is given to language aspects } \\
\text { (grammar and vocabulary). }\end{array}$ & 166.0 & 3.95 & 79.05 & High \\
\hline 3 & $\begin{array}{l}\text { Attention is given to mechanics } \\
\text { (spelling and punctuation). }\end{array}$ & 152.0 & 3.62 & 72.38 & High \\
\hline 4 & $\begin{array}{l}\text { Attention is given to writing genre } \\
\text { format. }\end{array}$ & 162.0 & 3.86 & 77.14 & High \\
\hline 5 & $\begin{array}{l}\text { Attention is given to writing } \\
\text { organization and coherence. }\end{array}$ & 166.0 & 3.95 & 79.05 & High \\
\hline 6 & $\begin{array}{l}\text { Attention is given to neat and legible } \\
\text { handwriting (penmanship). }\end{array}$ & 160.0 & 3.81 & 76.19 & High \\
\hline 7 & $\begin{array}{l}\text { Attention is given to writing } \\
\text { accuracy. }\end{array}$ & 162.0 & 3.86 & 77.14 & High \\
\hline 8 & Attention is given to writing clarity. & 164.0 & 3.90 & 78.10 & High \\
\hline 9 & $\begin{array}{l}\text { Writing is taken into consideration } \\
\text { functionally and communicatively. }\end{array}$ & 168.0 & 4.00 & 80.00 & $\begin{array}{l}\text { Very } \\
\text { High }\end{array}$ \\
\hline 10 & $\begin{array}{l}\text { The writing tasks can be easily } \\
\text { supplemented and modified. }\end{array}$ & 154.0 & 3.67 & 73.33 & High \\
\hline \multirow{2}{*}{\multicolumn{2}{|c|}{$\begin{array}{l}\text { Total score of the Writing Skill \& Sub- } \\
\text { Skills Domain. }\end{array}$}} & 1626.0 & 38.71 & 77.43 & \multirow[t]{2}{*}{ High } \\
\hline & & \multicolumn{2}{|c|}{ Std. Deviation } & 6.113 & \\
\hline
\end{tabular}

Table (4) indicates that Item (1) is the highest with percentage $(81.90 \%)$, and Item (3) is the lowest with percentage $(72.38 \%)$. It illustrates that the degree of evaluation was from "Very High" downward to "High". The average degree of the total score of the Writing Skill \& Sub-Skills Domain is "High". 
D. Writing Themes Domain Table (5)

Sum of Responses, Means, Std. Deviation, \% Weight and Level/Degree

\begin{tabular}{|c|c|c|c|c|c|}
\hline No. & Items & Sum & Mean & $\begin{array}{c}\% \\
\text { Weight }\end{array}$ & $\begin{array}{l}\text { Level/ } \\
\text { Degree }\end{array}$ \\
\hline 1 & $\begin{array}{l}\text { There is sufficient variety of writing } \\
\text { themes and models. }\end{array}$ & 170.0 & 4.05 & 80.95 & Very High \\
\hline 2 & $\begin{array}{l}\text { The writing themes are authentic (natural } \\
\text { and real language situations). }\end{array}$ & 164.0 & 3.90 & 78.10 & High \\
\hline 3 & $\begin{array}{l}\text { The writing themes are compatible with } \\
\text { students' needs and interests. }\end{array}$ & 162.0 & 3.86 & 77.14 & High \\
\hline 4 & $\begin{array}{l}\text { The writing themes are related to students' } \\
\text { culture and environment. }\end{array}$ & 148.0 & 3.52 & 70.48 & High \\
\hline 5 & $\begin{array}{l}\text { The writing themes foster the national } \\
\text { values and tradition. }\end{array}$ & 150.0 & 3.57 & 71.43 & High \\
\hline 6 & $\begin{array}{l}\text { The writing themes are consistent with } \\
\text { students' ambition and future career. }\end{array}$ & 148.0 & 3.52 & 70.48 & High \\
\hline 7 & The writing themes build positive attitudes. & 158.0 & 3.76 & 75.24 & High \\
\hline 8 & $\begin{array}{l}\text { The writing themes appeal to students' } \\
\text { motivation. }\end{array}$ & 156.0 & 3.71 & 74.29 & High \\
\hline 9 & $\begin{array}{c}\text { The writing themes serve as a window into } \\
\text { learning about the English language } \\
\text { culture. }\end{array}$ & 170.0 & 4.05 & 80.95 & Very High \\
\hline 10 & $\begin{array}{l}\text { The writing themes are supported by the } \\
\text { textbook content and coincided with } \\
\text { similar themes of other skills. }\end{array}$ & 148.0 & 3.52 & 70.48 & High \\
\hline \multirow{2}{*}{\multicolumn{2}{|c|}{ Total score of the Writing Themes Domain }} & 1574.0 & 37.47 & 74.95 & \multirow[t]{2}{*}{ High } \\
\hline & & \multicolumn{2}{|c|}{ Std. Deviation } & 8.846 & \\
\hline
\end{tabular}

Table (5) indicates that Items (1 \& 9) are the highest with percentage $(80.95 \%)$, and Items $(4,6 \& 10)$ are the lowest with percentage $(70.48 \%)$. It illustrates that the degree of evaluation was from "Very High" downward to "High". The average degree of the total score of the Writing Themes Domain is "High". 
E. Teachers' Attitudes Domain Table (6)

Sum of Responses, Means, Std. Deviation, \% Weight and Level/Degree

\begin{tabular}{|c|c|c|c|c|c|}
\hline No. & Items & Sum & Mean & $\begin{array}{c}\% \\
\text { Weight }\end{array}$ & $\begin{array}{l}\text { Level/ } \\
\text { Degree }\end{array}$ \\
\hline 1 & $\begin{array}{l}\text { Teaching the writing activities of the } \\
\text { textbook is enjoyable and } \\
\text { comfortable. }\end{array}$ & 156.0 & 3.71 & 74.29 & High \\
\hline 2 & $\begin{array}{l}\text { Following the instructional } \\
\text { procedures of the teacher's book is } \\
\text { encouraging and motivating. }\end{array}$ & 156.0 & 3.71 & 74.29 & High \\
\hline 3 & $\begin{array}{l}\text { There are no problems in getting } \\
\text { students interested in the writing } \\
\text { activities and involved in } \\
\text { communicative meaningful writing } \\
\text { situations. }\end{array}$ & 156.0 & 3.71 & 74.29 & High \\
\hline 4 & $\begin{array}{l}\text { Some of the writing activities are } \\
\text { difficult for most of the students to } \\
\text { deal with. }\end{array}$ & 156.0 & 3.71 & 74.29 & High \\
\hline 5 & $\begin{array}{l}\text { The up to date variety of the writing } \\
\text { activities in the textbooks is } \\
\text { satisfying. }\end{array}$ & 162.0 & 3.86 & 77.14 & High \\
\hline 6 & $\begin{array}{l}\text { The size of the writing activities is } \\
\text { appropriate and adequate. }\end{array}$ & 144.0 & 3.43 & 68.57 & Moderate \\
\hline 7 & $\begin{array}{l}\text { The writing skill weight is balanced } \\
\text { and suitable in comparison with the } \\
\text { other language skills. }\end{array}$ & 138.0 & 3.29 & 65.71 & Moderate \\
\hline 8 & $\begin{array}{l}\text { Focus is on quality of writing rather } \\
\text { than quantity of writing. }\end{array}$ & 132.0 & 3.14 & 62.86 & Moderate \\
\hline 9 & $\begin{array}{l}\text { Time allocated is adequate to get } \\
\text { students participate and practice the } \\
\text { scheduled writing activities. }\end{array}$ & 140.0 & 3.33 & 66.67 & Moderate \\
\hline 10 & $\begin{array}{l}\text { Students' performance in the writing } \\
\text { activities is satisfactory. }\end{array}$ & 134.0 & 3.19 & 63.81 & Moderate \\
\hline \multirow{2}{*}{\multicolumn{2}{|c|}{$\begin{array}{c}\text { Total score of the Teachers' Attitudes } \\
\text { Domain }\end{array}$}} & 1474.0 & 35.09 & 70.19 & \multirow[t]{2}{*}{ High } \\
\hline & & \multicolumn{2}{|c|}{ Std. Deviation } & 10.956 & \\
\hline
\end{tabular}

Table (6) indicates that Item (5) is the highest with percentage $(77.14 \%)$, and Item (8) is the lowest with percentage $(62.86 \%)$. It illustrates that the degree of evaluation was from "High" downward to "Moderate". The average degree of the total score of the Teachers' Attitudes Domain is "High".

To answer the third sub-question which is: "What are the degrees of evaluation for the writing activities included in the New Edition of English for Palestine 12 from teachers' perspective?" Sum, Means, Standard Deviations, and \%Weight were computed, 
and Number of participants, Number of items, and Level/degree are also provided for the Pedagogical Skill domain, EFL Methodology domain, Writing Skill \& Sub-Skills domain, Writing Themes domain and Teachers' Attitudes domain which are evaluated in the current study.

The Total Scores of the Five Domains Table (7)

Sum of Responses, Means, Std. Deviation, \% Weight and Level/Degree

\begin{tabular}{|c|c|c|c|c|c|c|c|c|}
\hline No. & Domains & $\mathbf{N}$. & Items & Sum & Means & $\begin{array}{c}\text { Std. } \\
\text { Deviation }\end{array}$ & $\begin{array}{c}\text { \% } \\
\text { Weight }\end{array}$ & $\begin{array}{c}\text { Level/ } \\
\text { Degree }\end{array}$ \\
\hline $\mathbf{1}$ & $\begin{array}{c}\text { Pedagogical } \\
\text { Skills }\end{array}$ & 42 & 10 & 1576.0 & 37.52 & 10.699 & 75.05 & High \\
\hline $\mathbf{2}$ & $\begin{array}{c}\text { FEL } \\
\text { Methodology }\end{array}$ & 42 & 10 & 1518.0 & 36.14 & 6.356 & 72.29 & High \\
\hline $\mathbf{3}$ & $\begin{array}{c}\text { Writing Skill } \\
\text { \& Sub-skills }\end{array}$ & 42 & 10 & 1626.0 & 38.71 & 6.113 & 77.43 & High \\
\hline $\mathbf{4}$ & $\begin{array}{c}\text { Writing } \\
\text { Themes }\end{array}$ & 42 & 10 & 1574.0 & 37.47 & 8.846 & 74.95 & High \\
\hline $\mathbf{5}$ & $\begin{array}{c}\text { Teachers' } \\
\text { Attitudes }\end{array}$ & 42 & 10 & 1474.0 & 35.09 & 10.956 & 70.19 & High \\
\hline & Total Score & 42 & 50 & 7768.0 & 184.95 & 9.991 & 73.98 & High \\
\hline
\end{tabular}

Table (7) reveals that the total level/degree of teachers' perspectives and attitudes towards the appropriateness and suitability of the Writing Activities included in the New Edition of English for Palestine 12 were high (positive) with (73.98\%), where, all the evaluated domains scored high percentage ranged between (77.43\%) downward to (70.98\%). The highest was the Writing Skill \& Sub-skills Domain with (77.43\%), the Pedagogical Skills Domain with (75.05), followed by the Writing Themes Domain with $(74.95 \%)$, then the FEL Methodology Domain with (72.29\%), and finally the Teachers' Attitudes Domain with (70.19\%). The scoring of Forty one items out of the fifty items of the five domains checklist ranged from "Very High" downward to "High", and nine items scored "Moderate". Yet, the average degree of the total score of all domains was "High". 
In addition, a Content Analysis Card has been done by the researcher in order to recognize the nature and type of the writing topics.

Table (8) A Content Analysis Card

\begin{tabular}{|c|c|c|}
\hline $\begin{array}{l}\text { Unit } \\
\text { No. }\end{array}$ & Writing Tasks & $\begin{array}{l}\text { Classification of } \\
\text { Writing Type }\end{array}$ \\
\hline \multicolumn{3}{|c|}{ New edition, English for Palestine 12, Pupil's Book } \\
\hline 1 & Completing a university application form & Functional Writing \\
\hline 2 & $\begin{array}{l}\begin{array}{l}\text { Planning and drafting a personal } \\
\text { statement }\end{array} \\
\end{array}$ & Functional Writing \\
\hline \multirow[b]{2}{*}{3} & Writing a story from a recount & Creative Writing \\
\hline & $\begin{array}{l}\text { Writing a story about a coincidence or } \\
\text { Misunderstanding }\end{array}$ & Creative Writing \\
\hline 4 & $\begin{array}{l}\text { Planning, writing and conducting a } \\
\text { questionnaire }\end{array}$ & Functional Writing \\
\hline 5 & $\begin{array}{l}\text { Planning and writing an essay about } \\
\text { communication methods }\end{array}$ & Creative Writing \\
\hline 6 & Revision & Mixed \\
\hline 7 & $\begin{array}{l}\text { Planning and writing a general enquiry } \\
\text { letter }\end{array}$ & Functional Writing \\
\hline 8 & Writing a short formal email & Functional Writing \\
\hline \multirow[b]{2}{*}{9} & Write a personal email & Functional Writing \\
\hline & $\begin{array}{l}\text { Plan and write a report of a sporting } \\
\text { event }\end{array}$ & Functional Writing \\
\hline 10 & Planning and writing a summary & Functional Writing \\
\hline 11 & Writing about a story of a memorable & Creative Writing \\
\hline 12 & Revision & Mixed \\
\hline \multicolumn{3}{|c|}{ New edition, English for Palestine 12, Pupil's Book - Reading Plus 1} \\
\hline 1 & $\begin{array}{l}\text { Rewriting a letter, Replying to a letter, } \\
\text { Writing resolutions }\end{array}$ & Functional Writing \\
\hline 2 & $\begin{array}{l}\text { Writing a notice, Writing a welcome page } \\
\text { for a community website }\end{array}$ & Functional Writing \\
\hline \multirow{3}{*}{3} & $\begin{array}{l}\text { Writing a paragraph showing the } \\
\text { opposite idea }\end{array}$ & Functional Writing \\
\hline & Planning a paragraph & Functional Writing \\
\hline & Completing an essay & Creative Writing \\
\hline$*$ & Progress Test 1(Writing an Essay) & Creative Writing \\
\hline \multirow{3}{*}{4} & Writing a formal letter & Functional Writing \\
\hline & Completing a proposal form & Functional Writing \\
\hline & Comparing formal and informal writing & Functional Writing \\
\hline 5 & $\begin{array}{l}\text { Writing an essay, Rhetorical question } \\
\text { and other persuasion techniques }\end{array}$ & Creative Writing \\
\hline 6 & Writing short biographies & Functional Writing \\
\hline$*$ & Progress Test 1(Writing an Essay) & Creative Writing \\
\hline$*$ & $\begin{array}{l}\text { Writing Samples are provided on page } \\
108\end{array}$ & Mixed \\
\hline
\end{tabular}


According to the Content Analysis Card as shown in table above 16 topics are considered as a functional writing, and 8 topics are considered as a creative writing, whereas units of revision are a mixture between functional writing and creative writing.

\section{Conclusion}

The study was designed to examine the appropriateness and suitability of the writing activities included in the New Edition of English for Palestine 12, which has been being taught for the first time in the scholastic year 2015/2016 for 12th grade students at the Palestinian schools. Accordingly, in reference to the results which have already been pointed out in the current study, the study concluded that the writing activities included in the New Edition of English for Palestine 12 is highly proved to be suitable for the 12th grade students at the Palestinian schools.

The participants were English language teachers for grade 12. They believed that all the checklist items were highly important. Therefore, as a final remark, it can be concluded that the writing activities included in the New Edition of English for Palestine 12 prescribed by the Ministry of Education and Higher Education meet the expectations of learners as the current study revealed. Reformation of the intended materials is by all means warranted as the most overarching teachers from among the existing stakeholders confirm this fact. Writing skill is a basic requirement to get familiar with using English in genuine situations functionally and communicatively.

The writing activities place much emphasis on writing as a process and they are more lenient on subskills, and this let other skills and components flourish. Based on the content analysis card the researcher employed; it revealed that the functional writing topics 
occupies about $67 \%$, whereas the creative writing topics occupies the rest out of the total of the writing activities, as shown in table (8) above.

The variety of functional writing topics is relevant to students' interests, needs and career. The writing activities stimulate students thinking skills. The writing skill is the pioneer of the growth of other language skills. They all go side by side with the development of the pedagogical skill.

Yet, there are certain pitfalls that should be avoided by teachers and developers of English Language Textbook; those which are embedded in the items that scored moderate degree.

\section{Recommendations}

* An adequate balance between the size of the writing materials and the time allocated for practicing writing activities more effectively should be reconsidered.

More attention should be paid to Self-Regulation Strategies (goal-setting, self-instruction, selfmonitoring, self-evaluating, self-reinforcement, etc.) to train students to be creative independent writers.

* Evaluative studies should be pioneered to cover the other language skills and language aspects.

Sustainable innovative programs should be pioneered to monitor, direct and develop teachers' professional skills and abilities in teaching English as a foreign Language. 


\section{Reference}

1. Abbas, I. (2011). Palestinian and Global Cultural Dimensions in English for Palestine Textbooks for Grades 11 \& 12. Journal of Al-Quds Open University for Research and Studies - No. 24 (1) - July 2011.

2. Abu Alhumous, O. (2010). Diagnosing Palestinian First Grade Students' Basic Mechanisms of EFL Reading. Paper presented at the Improving TEFL Methods \& Practices at Palestinian Universities, First National Conference. Al-Quds Open University, Ramallah Palestine.

3. Abu Ashiba, S. (2010). "An Analysis of the Incorporated Values in English for Palestine 12". Unpublished M. A. Thesis. The Islamic University of Gaza, Palestine.

4. Akef, H. (2015). Evaluating the English Textbook "IRAQ OPPORTUNITIES" Book 6 for the 2nd Intermediate Stage. AL-USTATH No 215 - 2015AD, 1437AH. Available at: www.iasj.net/iasj?func $=$ fulltext $\&$ aId $=107078$

5. Ali, N. (2010). "An Evaluation of the Reading Texts \& Exercises in SB \& WB of English for Palestine - Grade 9. Unpublished M. A. Thesis. The Islamic University of Gaza, Palestine".

6. Al-Mazloum, M. (2007). "Evaluating the Content of English for Palestine Grade Ten Textbook in the Light of the Standards for Foreign Language Learning". Unpublished M. A. Thesis. The Islamic University of Gaza, Palestine. 
7. Al-Najjar, R. (2012). "An Evaluation of Pronunciation Teaching Content of English for Palestine 10 and Related Teachers' Competency Level in Light of Current Instructional Perspectives". Unpublished M. A. Thesis. The Islamic University of Gaza, Palestine.

8. Anjaneyulu, T. (2014). A Critical Analysis of the English Language Textbooks in Andhra Pradesh, India. International Association of Research in Foreign Language Education and Applied Linguistics ELT Research Journal 2014, 3(4), 181200. Available online at: http://www.eltrj.com

9. Aqel, A. (2009). "An Evaluative Study of the Palestinian 11th Grade English Textbook from the Teachers' Perspective in Southern Nablus and Salfit Districts". Unpublished M. A. Thesis, AnNajah University, Palestine.

10. Awad, A. (2013). Evaluating English for Palestine 12 in Terms of the EFL/ ESL Textbook Evaluating Checklist from the Teachers' Perspectives in Nablus Directorate Schools. AnNajah University Journal Research (Humanities). Vol. 27(11).

11. Badawi, M. (2007). Studies in Curriculum \& Instruction. Issues No. 124. Tabouk Teacher' College, Kingdom of Saudi Arabia.

12. Brown, H. (4th Ed.). (2000). Principles of Language Learning and Teaching. N.Y.: Longman.

13. Cunningsworth, A. (1995). Choosing Your Course Book. Oxford: Heinemann.

14. Cunningsworth, A. (1984). Evaluating and Selecting EFL Materials. London: Heinemann.

15. Ellis, R. (1997). SLA Research and Language

Teaching. Oxford: Oxford University Press. 
16. El-Shawa, N. (2011). "Evaluating the Cultural Content of English for Palestine Secondary Stage Textbooks in the Light of Universal Trends". Unpublished M. A. Thesis. The Islamic University of Gaza, Palestine.

17. Faqawi, H. (2010). "The Availability of the NCTE Standards in the Content of 8th Grade Curriculum of English in Palestine". Unpublished M. A. Thesis. AL- Azhar University, Palestine.

18. Fattash, M. (2010). Congruity or Disparity:

Teachers' Assessment of the New Palestinian English Language School Curriculum. TESOL Journal, 2, 189-206.

19. Garinger, D. (2002). Textbook selection for the ESL classroom. Southern Alberta Institute of Technology. Available online at: http://www.cal.org/resources/digest/0210garinger.h tml

20. Graham, S. (2006b). Strategy Instruction and the Teaching of Writing: A Meta-Analysis. In C. A. McArther, S. Graham, \& Fitzgeral (Eds.), Handbook of Writing Research (pp. 187-208). New York, NY: Gilford Press.

21. Hamdona, Y. (2007). "Life Skills Latent in the Content of English for Palestine - Grade Six Textbook". Unpublished M. A. Thesis. The Islamic University of Gaza. Gaza. Palestine.

22. Hammad, E. (2014). Palestinian EFL Teachers' Attitudes Towards English Textbooks Used at the First Three Grades of Elementary School. The Electronic Journal for English as a Second Language, May 2014 - Volume 18, Number 1. Available at: www.teslej.org/wordpress/issues/volume18/.../ej69a3/ 
23. Harmer, J. (2007). The Practice of English Language Teaching. (4th edition). Harlow: London.

24. Hedge, T. (2000). Teaching and Learning in the Language Classroom. Oxford: Oxford University Press.

25. Henriques, S. (2009). "An Evaluation of English as a Foreign Language Textbooks for Secondary Schools in Angola". Ph. D. Thesis, University of Kansas.

26. John, S., Abdul Aziz, S., Ahmed, A., Sharf, N., \& Ishaque, M. (2014). Evaluation of English Language Textbooks Prescribed by Sindh Textbook Board for Intermediate Level: Issue of Conformity to the National English Curriculum Objectives. Quest Journals, Journal of Research in Humanities and Social Science. Volume $2 \sim$ Issue 7 (2014) pp: 33-45, ISSN2321-9467. Available online at: www.questjournals.org

27. Krashen, D. (1984). Immersion: Why It Works and What It has Taught Us. Language and Society, 12, 61-64.

28. Masri, S. (2004). "Teachers' Evaluation of First Graders' English for Palestine. in the Northern Directorates of Palestine". Unpublished M.A Thesis, An-Najah National University, Nablus, Palestine.

29. Miekley, J. (2005). ESL Textbook Evaluation Checklist. The Reading Matrix_Vol. 5, No. 2. Available online at: mieklejp@email.uc.edu

30. Mohamoud, A. (2008): Analysing "English for

Palestine 10th Textbook" in Terms of the Characteristics of a Good English Textbook. AlQuds Open University. Vol. 13/1/2008. 
31. Mukundan, J. (2010). Retrotext-E 1.0: The Beginnings of Computer-Based ELT Textbook Evaluation. Advances in Language and Literary Studies, 1(2), 270-280.

32. Mukundan,J., Nimehchisalem, V., \& Hajimohammadi, R. (2011). Developing an English Language Textbook Evaluation Checklist. Contemporary Issues In Education Research June 2011, Volume 4, Number 6, Universiti Putra Malaysia, Malaysia.

33. Mukundan, J., Nimehchisalem, V., \& Hajimohammadi, R. (2011). Developing an English Language Textbook Evaluation Checklist: A Focus Group Study. International Journal of Humanities and Social Science,_Vol. 1 No. 12; September 2011, Universiti Putra Malaysia, 43400 UPM Serdang Selangor, Malaysia.

34. Mukundan, J. \& Nimehchisalem, V. (2012).

Evaluating the Validity and Economy of the English Language Teaching Textbook Evaluation Checklist. World Applied Sciences Journal, 20 (3): 458-463, 2012, IDOSI Publications.

35. Newby, D. (2000). Syllabus and Curriculum Design. In Byram, 590-594.

36. Richards, J. (2001). Curriculum Development in Language Teaching. Cambridge University Press. New York, USA.

37. Shaath, A. (2010). "Evaluation of Grade 10 English Language Student's Book of the Palestinian Syllabus from Teachers' Perspective". Unpublished M. A. Thesis, Joint Supervision Postgraduate Program, Ain Shams University and Al-Aqsa University. 
38. Shaath, A. (2015). "A Suggested Program Based on Self-Regulated Strategy Development for Developing Functional Writing Skills of Students at Al-Azhar University - Gaza ". Unpublished Ph. D. Thesis, Ain Shams University, Egypt.

39. Sheldon, L. (1988). Evaluating ELT Textbooks and Materials. English Language Teaching Journal, 42(4), 237-246.

40. Senior, R. (2006). The Experience of Language Teaching. U.K.: Cambridge University Press.

41. Schutz, R. (2002). Vygotsky and Language Acquisition. Available online at: http://www.sk.com.br-Vygot.html

42. Tok, H. (2010). TEFL Textbook Evaluation: From Teachers' Perspectives. Academic Journals, Educational Research and Review, Vol. 5 (9). Available online at: http://www.academicjournals.org/ERR2

43. Tomlinson, B. (2001). Materials Development.

In R. Carter \& D. Nunan (Eds.), Teaching English to Speakers of Other Languages (pp. 66-71). Cambridge: Cambridge University Press.

44. Tomlinson, B. (2003). Materials Evaluation. In

B. Tomlinson (Ed.), Developing Materials for Language teaching (pp. 15-36). London: Continuum International Publishing Group.

45. Walker, D. (2003). Fundamentals of Curriculum: Passion and Professionalism. (2nd Ed.) Lawrence Erlbaum Associates, Inc. N.J: Mahwah.

46. Woodward, T. (2000). Planning Lessons and

Courses. Cambridge: Cambridge University Press. 
In the Name of Allah, the Compassionate, the Merciful

\section{A Checklist}

Dear Teacher ,”,

The following checklist is designed for the purpose of collecting data for a research entitled:

\section{An Evaluation of the Writing Activities in the New Edition of English for Palestine 12 from Teachers' Perspective}

You are kindly invited to go through the items of the checklist, and then express your opinion about the checklist items. Please, tick $(\sqrt{ })$ the appropriate choice accurately and objectively.

*This checklist is used for the purpose of the research only.

Personal Information:

* Gender:

Male:

Female:

Qualification:

B. A.:

M. A.:

*xperience:

Less than 5 years:

More than 5 years:

I really appreciate your participation, cooperation and effort.

With My Best Regards

The Researcher

Dr. Atef M. R. Shaath

Email: atefshaat66@yahoo.com 
A Checklist:

Writing Activities Evaluation

\begin{tabular}{|c|c|c|c|c|c|c|}
\hline No. & St & $\begin{array}{l}\text { Strongly } \\
\text { agree } \\
\text { (5) }\end{array}$ & $\begin{array}{c}\text { Agree } \\
\text { (4) }\end{array}$ & $\begin{array}{c}\text { Moderate } \\
\text { (3) } \\
\end{array}$ & $\begin{array}{c}\text { Disagree } \\
(2) \\
\end{array}$ & $\begin{array}{c}\text { Strongly } \\
\text { disagree } \\
\text { (1) }\end{array}$ \\
\hline $\mathbf{A}$ & \multicolumn{6}{|c|}{$\begin{array}{l}\text { Pedagogical Skills Domain } \\
\end{array}$} \\
\hline 1 & $\begin{array}{l}\text { The writing activities } \\
\text { involve students in the } \\
\text { brainstorming process. }\end{array}$ & & & & & \\
\hline 2 & $\begin{array}{l}\text { The writing activities } \\
\text { stimulate the higher } \\
\text { level thinking skills. }\end{array}$ & & & & & \\
\hline 3 & $\begin{array}{l}\text { The writing activities } \\
\text { promote creativity. }\end{array}$ & & & & & \\
\hline 4 & $\begin{array}{l}\text { The writing activities } \\
\text { motivate students to } \\
\text { participate in class } \\
\text { work. }\end{array}$ & & & & & \\
\hline 5 & $\begin{array}{l}\text { The writing activities } \\
\text { reinforce individual } \\
\text { work and autonomy. }\end{array}$ & & & & & \\
\hline 6 & $\begin{array}{l}\text { The writing activities } \\
\text { incorporate pair and } \\
\text { group work, and } \\
\text { collaborative writing. }\end{array}$ & & & & & \\
\hline 7 & $\begin{array}{lr}\text { The writing } & \text { activities } \\
\text { enhance } & \text { Self- } \\
\text { Regulation Strategies } \\
\text { (goal-setting, self- } \\
\text { instruction, } & \text { self- } \\
\text { monitoring, } & \text { self- } \\
\text { evaluating, self- } & \text { selinforcement, etc.). }\end{array}$ & & & & & \\
\hline 8 & $\begin{array}{l}\text { The writing activities } \\
\text { develop self-reflective } \\
\text { writing. }\end{array}$ & & & & & \\
\hline 9 & $\begin{array}{l}\text { The writing activities } \\
\text { demonstrate students' } \\
\text { ability to generate } \\
\text { ideas, and enhance } \\
\text { free writing. }\end{array}$ & & & & & \\
\hline 10 & $\begin{array}{lr}\text { The writing } & \text { activities } \\
\text { participate } & \text { in } \\
\text { increasing } & \text { writing } \\
\text { knowledge } & \text { and } \\
\text { awareness. } & \end{array}$ & & & & & \\
\hline
\end{tabular}




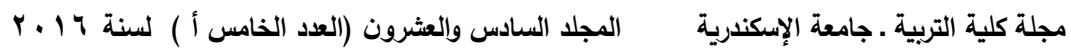

\begin{tabular}{|c|c|c|c|c|c|c|}
\hline B & \multicolumn{6}{|c|}{ EFL Methodological Domain } \\
\hline 1 & $\begin{array}{lr}\text { The } & \text { writing } \\
\text { activities } & \text { are } \\
\text { purposeful. } & \\
\end{array}$ & & & & & \\
\hline 2 & $\begin{array}{l}\text { The periods of the } \\
\text { writing activities } \\
\text { have achievable } \\
\text { goals. }\end{array}$ & & & & & \\
\hline 3 & $\begin{array}{l}\text { Instructions of the } \\
\text { writing activities are } \\
\text { clear and } \\
\text { understandable. }\end{array}$ & & & & & \\
\hline 4 & $\begin{array}{l}\text { Students } \\
\text { involved in the } \\
\text { writing process } \\
\text { steps (planning/pre- } \\
\text { writing, drafting, } \\
\text { revising, and } \\
\text { editing). }\end{array}$ & & & & & \\
\hline No. & Items & $\begin{array}{l}\text { Stron } \\
\text { gly } \\
\text { agree } \\
(5) \\
\end{array}$ & $\begin{array}{l}\text { Agree } \\
\text { (4) }\end{array}$ & $\begin{array}{l}\text { Moderate } \\
\text { (3) }\end{array}$ & $\begin{array}{c}\text { Disagree } \\
\text { (2) }\end{array}$ & $\begin{array}{l}\text { Strongly } \\
\text { disagree } \\
\text { (1) }\end{array}$ \\
\hline 5 & $\begin{array}{l}\text { The writing } \\
\text { activities assist } \\
\text { students who are } \\
\text { under/over- } \\
\text { achievers and take } \\
\text { into consideration } \\
\text { the individual } \\
\text { differences. }\end{array}$ & & & & & \\
\hline 6 & $\begin{array}{lr}\text { The writing } \\
\text { activities } \\
\text { compatible with the } \\
\text { diversity } \\
\text { students' } \\
\text { background } \\
\begin{array}{l}\text { knowledge } \\
\text { capabilities. . }\end{array} \\
\end{array}$ & & & & & \\
\hline 7 & $\begin{array}{l}\text { The writing } \\
\text { activities are graded } \\
\text { and progressive, } \\
\text { and tasks move } \\
\text { from simple to } \\
\text { complex. }\end{array}$ & & & & & \\
\hline
\end{tabular}




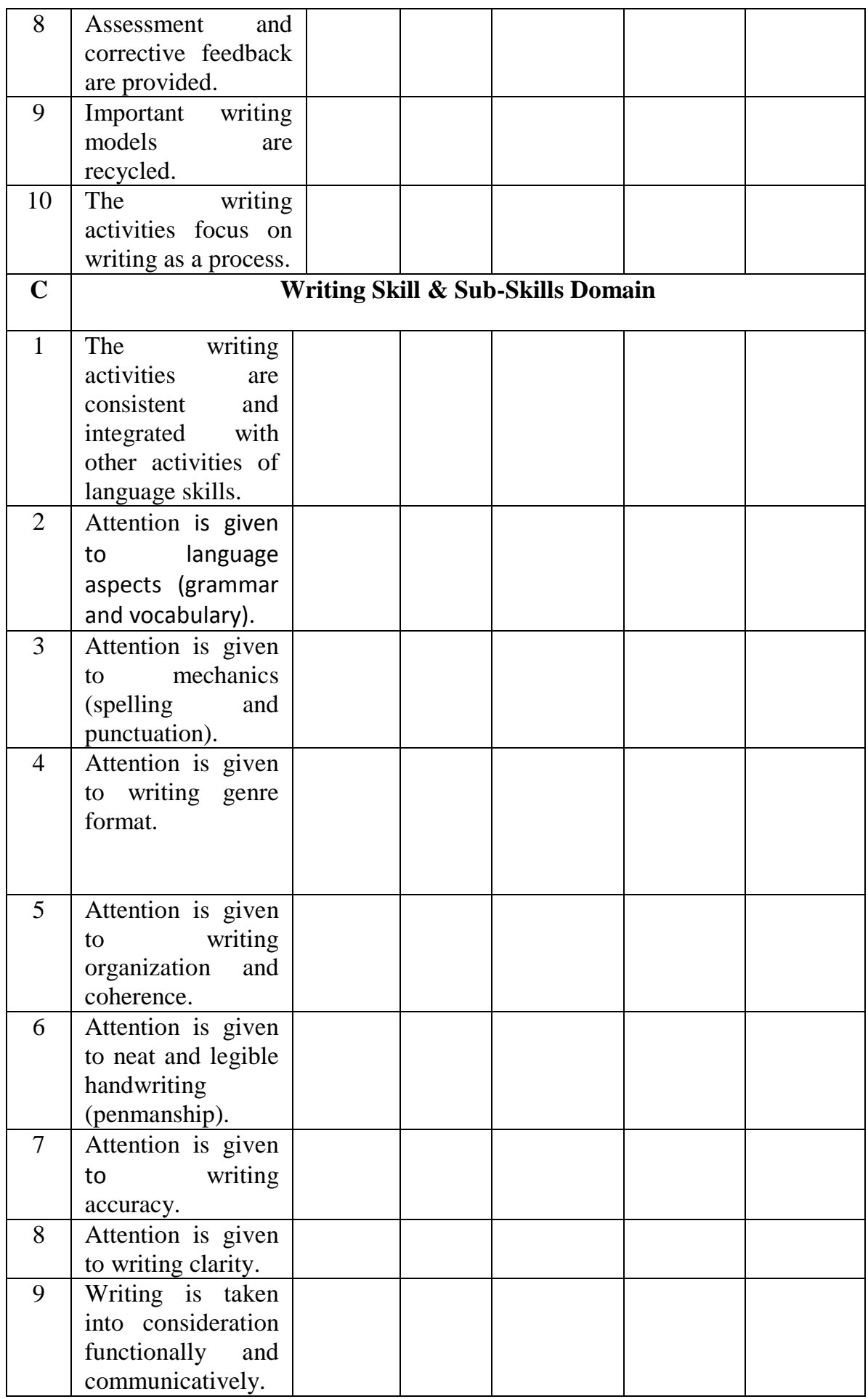




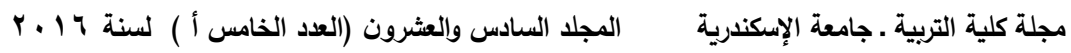

\begin{tabular}{|c|c|c|c|c|c|c|}
\hline 10 & $\begin{array}{l}\text { The writing tasks } \\
\text { can be easily } \\
\text { supplemented and } \\
\text { modified. }\end{array}$ & & & & & \\
\hline No. & Items & $\begin{array}{l}\text { Strong } \\
\text { ly } \\
\text { agree } \\
(5) \\
\end{array}$ & $\begin{array}{l}\text { Agree } \\
\text { (4) }\end{array}$ & $\begin{array}{c}\text { Moderate } \\
\text { (3) }\end{array}$ & $\begin{array}{c}\text { Disagree } \\
\text { (2) }\end{array}$ & $\begin{array}{c}\text { Strongly } \\
\text { disagree } \\
\text { (1) }\end{array}$ \\
\hline D & \multicolumn{6}{|c|}{ Writing Themes Domain } \\
\hline 1 & $\begin{array}{l}\text { There is sufficient } \\
\text { variety of writing } \\
\text { themes and models. }\end{array}$ & & & & & \\
\hline 2 & $\begin{array}{l}\text { The writing themes } \\
\text { are authentic } \\
\text { (natural and real } \\
\text { language } \\
\text { situations). }\end{array}$ & & & & & \\
\hline 3 & $\begin{array}{l}\text { The writing themes } \\
\text { are compatible with } \\
\text { students' needs and } \\
\text { interests. }\end{array}$ & & & & & \\
\hline 4 & $\begin{array}{l}\text { The writing themes } \\
\text { are related to } \\
\text { students' culture and } \\
\text { environment. }\end{array}$ & & & & & \\
\hline 5 & $\begin{array}{l}\text { The writing themes } \\
\text { foster the national } \\
\text { values and tradition. }\end{array}$ & & & & & \\
\hline 6 & $\begin{array}{l}\text { The writing themes } \\
\text { are consistent with } \\
\text { students' ambition } \\
\text { and future career. }\end{array}$ & & & & & \\
\hline 7 & $\begin{array}{l}\text { The writing themes } \\
\text { build positive } \\
\text { attitudes. }\end{array}$ & & & & & \\
\hline 8 & $\begin{array}{l}\text { The writing themes } \\
\text { appeal to students' } \\
\text { motivation. }\end{array}$ & & & & & \\
\hline 9 & $\begin{array}{l}\text { The writing themes } \\
\text { serve as a window } \\
\text { into learning about } \\
\text { the English } \\
\text { language culture. }\end{array}$ & & & & & \\
\hline 10 & $\begin{array}{l}\text { The writing themes } \\
\text { are supported by the } \\
\text { textbook content } \\
\text { and coincided with } \\
\text { similar themes of } \\
\text { other skills. }\end{array}$ & & & & & \\
\hline
\end{tabular}




\begin{tabular}{|c|c|c|c|c|c|c|}
\hline $\mathbf{E}$ & \multicolumn{6}{|c|}{ Teachers' Attitudes Domain } \\
\hline 1 & $\begin{array}{l}\text { Teaching the } \\
\text { writing activities } \\
\text { of the textbook is } \\
\text { enjoyable and } \\
\text { comfortable. }\end{array}$ & & & & & \\
\hline 2 & $\begin{array}{l}\text { Following the } \\
\text { instructional } \\
\text { procedures of the } \\
\text { teacher's book is } \\
\text { encouraging and } \\
\text { motivating. }\end{array}$ & & & & & \\
\hline 3 & $\begin{array}{l}\text { There are no } \\
\text { problems in } \\
\text { getting students } \\
\text { interested in the } \\
\text { writing activities } \\
\text { and involved in } \\
\text { communicative } \\
\text { meaningful writing } \\
\text { situations. }\end{array}$ & & & & & \\
\hline 4 & $\begin{array}{l}\text { Some of the } \\
\text { writing activities } \\
\text { are difficult for } \\
\text { most of the } \\
\text { students to deal } \\
\text { with. }\end{array}$ & & & & & \\
\hline No. & Items & $\begin{array}{l}\text { Strong } \\
\text { ly } \\
\text { agree } \\
(5)\end{array}$ & $\begin{array}{c}\text { Agree } \\
\text { (4) }\end{array}$ & $\begin{array}{c}\text { Moderate } \\
\text { (3) }\end{array}$ & $\begin{array}{c}\text { Disagree } \\
\text { (2) }\end{array}$ & $\begin{array}{l}\text { Strongly } \\
\text { disagree } \\
\text { (1) }\end{array}$ \\
\hline 5 & $\begin{array}{l}\text { The up to date } \\
\text { variety of the } \\
\text { writing activities } \\
\text { in the textbooks is } \\
\text { satisfying. }\end{array}$ & & & & & \\
\hline 6 & $\begin{array}{l}\text { The size of the } \\
\text { writing activities is } \\
\text { appropriate and } \\
\text { adequate. }\end{array}$ & & & & & \\
\hline 7 & $\begin{array}{l}\text { The writing skill } \\
\text { weight is balanced } \\
\text { and suitable in } \\
\text { comparison with } \\
\text { the other language } \\
\text { skills. }\end{array}$ & & & & & \\
\hline 8 & $\begin{array}{l}\text { Focus is on quality } \\
\text { of writing rather } \\
\text { than quantity of } \\
\text { writing. }\end{array}$ & & & & & \\
\hline
\end{tabular}




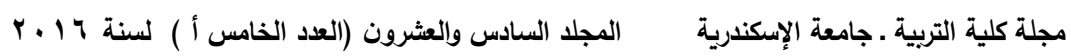

\begin{tabular}{|l|l|l|l|l|l|}
\hline 9 & $\begin{array}{l}\text { Time allocated is } \\
\text { adequate to get } \\
\text { students and } \\
\text { participate and } \\
\text { practice the } \\
\text { scheduled writing } \\
\text { activities. }\end{array}$ & & & & \\
\hline 10 & $\begin{array}{l}\text { Students } \\
\text { performance in the } \\
\text { writing activities is } \\
\text { satisfactory. }\end{array}$ & & & & \\
\hline
\end{tabular}

\section{Additional Notes:}

Advantages:

\section{Disadvantages:}

\section{Thank you for your cooperation}

*I really appreciate your participation and effort. 


\begin{abstract}
The current study aimed at evaluating the writing activities included in the new edition of "English for Palestine 12" from teachers' perspective. To accomplish the aim of the study, the researcher administered a validated designed checklist of fifty items categorized into five domains. Forty two 12th grade English language teachers at schools of Khan Younis directorates were chosen randomly. They determined the appropriate choices for the checklist's items, during the second semester of the scholastic year 2015-2016. Findings of the study revealed that the total degree of the evaluation is "High", which emphasize the appropriateness of the writing activities for the 12th grade students at the Palestinian schools.

Key words: An Evaluation of Writing Activities, English for Palestine 12, Teachers' Perspectives.
\end{abstract}

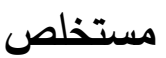

هدفت الدراسـة الحاليـة إلى تقيـيم الأنشطة الكتابـة المدرجـة في الطبعـة

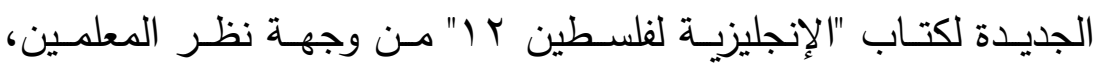
ولتحقيق هدف الدراسة، قام الباحث بتطبيق الاستبانة المصممة والتي تم

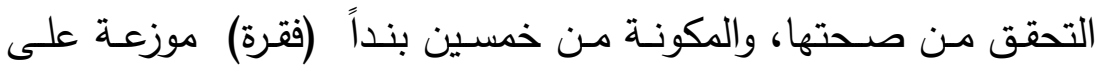
خمسـة مجالات، وقد شـارك اثنان وأربعون من معلمي اللغنة الإنجليزيـة للصـف الثاني عشـر في مـدارس مـديريات خـان يـونس، تم اختيـارهم عشوائياً، حيث قاموا بتحديد الإختيارات الملاءمـة لبنود الاستبانة خلال

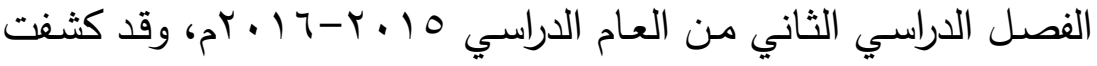

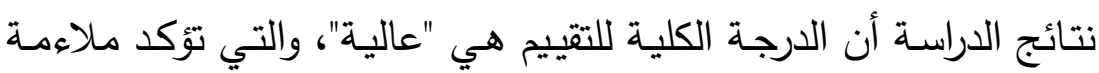
الأنشطة الكتابية لطلاب الصف الثاني عشر في المدارس الفلسطينية.

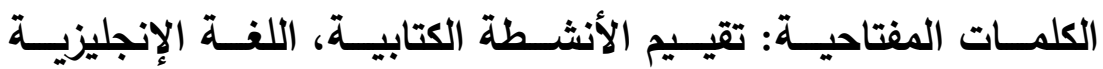
لفلسطين Y 1 ، وجهات نظر المعلمين. 